\title{
The $\alpha$-Effect and Mechanism of Reactions of Y-Substituted Phenyl Benzenesulfonates with Hydrogen Peroxide Ion
}

\author{
Li-Ra Im and Ik-Hwan Um
}

\author{
Department of Chemistry and Nano Science, Ewha Homans University, Seoul 120-750, Korea \\ ${ }^{*}$ E-mail: ihtmatewhac. $\mathrm{kr}$ \\ Received August 6. 2009. Accepted September +. 2009
}

\begin{abstract}
Second-order rate constants $\left(k_{\mathrm{HOO}}\right)$ ) have been measured spectrophotometrically for nucleophilic substitution reactions of $\mathrm{Y}$-substituted phenyl benzenesulfonates $(\mathbf{1 a - g})$ with $\mathrm{HOO}^{-}$ion in $\mathrm{H}_{2} \mathrm{O}$ at $25.0 \pm 0.1^{\circ} \mathrm{C}$. The Bronsted-type plot is linear with $\beta_{l o}=-0.73$. The Hammett plot correlated with with $\sigma^{-}$constants results in much better linearity than $\sigma^{\circ}$ constants, indicating that expulsion of the leaving group occurs in the rate-determining step (RDS) either in a stepwise mechanisn or in a concerted pathway. However, a stepwise mechanism in which departure of the leaving group occurs in the RDS has been excluded since HOO' ion is more basic and a poorer leaving group than the leaving $\mathrm{Y}$-substituted phenoxide ions. Thus, the reactions of 1 a-g with $\mathrm{HOO}^{-}$ion have been concluded to proceed through a concerted mechanism. The $\alpha$-nucleophile $\mathrm{HOO}^{-}$ion is more reactive than its reference nucleophile $\mathrm{OH}^{-}$ion although the former is $c a .4 \mathrm{pK}$ a units less basic than the latter (i.e., the $\alpha$-effect). TS stabilization through intramolecular $\mathrm{H}$-bonding interaction has been suggested to be irresponsible for the $a$-effect shown by $\mathrm{HOO}^{-}$ion, since the magnitude of the $\alpha$-effect is independent of the electronic nature of substituent $\mathrm{Y}$ in the leaving group. GS destabilization through desolvation of $\mathrm{HOO}^{-}$ion has been concluded to be responsible for the $\alpha$-effect found in the this study.
\end{abstract}

Key Words: The $\alpha$-Effect. Bronsted-type plot. Hammett plot, Intramolecular H-bonding. Solvent effect

\section{Introduction}

The term $\alpha$-effect was given to the abnormally enhanced reactivity exhibited by nucleophiles possessing one or more nonbonding electron pairs at the atom $\alpha$ to the nucleophilic

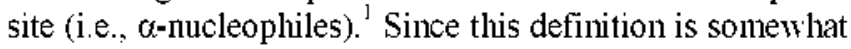
ambiguous. an alternative definition of the $\alpha$-effect was proposed. i.e.. a positive deviation exhibited by an $\alpha$-nucleophile from a Bronsted-type nucleophilicity plot. ${ }^{2}$ However. stnicturally nucleophiles have often been used as the $\alpha$ - and reference nucleophiles, e.g. $\mathrm{HOO}^{-}$is. $\mathrm{OH}^{-}$and ${ }^{\mathrm{s}} \mathrm{BuOO}^{-}$is. ${ }^{t} \mathrm{BuO}{ }^{-3-5}$

Numerous studies have been performed to investigate the cause of the $\alpha$-effect. Some important theories to explain the cause of the $\alpha$-effect include ground-state (GS) destabilization due to the repulsion between the nonbonding electron pairs. transition-state (TS) stabilization including intramolecular general acid/base catalysis, thermody namic product stabilization, and solvent effects. ${ }^{6-i-1}$ However, none of these theories can explain the cause of the $\alpha$-effect. Particularly, theories of solvent effect on the $\alpha$-effect are controversial. ${ }^{15.16}$ DePuy et al. found that $\mathrm{HOO}^{-}$does not exhibit any enhanced micleophilic reactivity in gas-phase reactions of methyl formate. ${ }^{136}$ Thus. the $\alpha$-effect shown by $\mathrm{HOO}^{-}$in aqueous solutions was attributed to a solvent effect. ${ }^{13}$ A contrary conclusion has been drawn from recent gas-phase studies including theoretical calculations. ${ }^{14-16}$ Patterson and Fountain found that $\alpha$-nucleophile $\mathrm{HOO}^{-}$ion exhibits $3.6 \mathrm{kcal} / \mathrm{mol}$ lower activation barrier than the reference nucleophile $\mathrm{EtO}^{-}$in gas-phase $\mathrm{S}_{\mathrm{N}} 2$ reactions and concluded that solvent effect on the $\alpha$-effect is not important. ${ }^{1+} \mathrm{A}$ similar conclusion has been drawn by McAnoy et al. from gas-phase reactions of dimethyl methylphospho- nate with $\mathrm{CD}_{3} \mathrm{O}^{-}$and $\mathrm{HOO}^{-}$anions in an ion-trap mass spectrometer. ${ }^{15}$ and by Yamataka et $a l$. from theoretical calculations at the $\mathrm{G} 2(+)$ level on gas-phase $\mathrm{S}_{\mathrm{N}} 2$ reactions of alkyl halides with 11 anionic nucleophiles. ${ }^{16}$

We have found that solvent effect on the $\alpha$-effect is significant in nucleophilic substitution reactions of various electrophilic center (e.g. aryl acetates. benzoates. and thionobenzoates) with butane-2.3-dione monoxintate ( $\mathrm{Ox}^{-}$. as an $\alpha$-nucleophile) and 4-chlorophenoxie (4-ClPhO${ }^{-}$, as a reference nucleophile) in DMSO- $\mathrm{H}_{2} \mathrm{O}$ mistures of varying compositions. ${ }^{6.1 \%}$ Our calorimetric study has revealed that $\mathrm{Ox}^{-}$is less strongly solvated than its reference nucleophile ${ }^{4-C I P h O}{ }^{-}$in DMSO$\mathrm{H}_{2} \mathrm{O}$ mistures (e.g., ca. $4 \mathrm{kcal} / \mathrm{mol}$ in $\mathrm{H}_{2} \mathrm{O}$ and over $7 \mathrm{kcal} / \mathrm{mol}$ in DMSO content above $40 \mathrm{~mol} \%$ ). ${ }^{195}$ It has also been found that the magnitude of the $\alpha$-effect is lughly dependent on the solvent compositions. i.e.. the $\alpha$-effect increases with increasing DMSO content in the medium up to $c a .50 \mathrm{~mol} \% \mathrm{DMSO}$ and decreases thereafter. resulting a bell-shaped $\alpha$-effect profile. $6.1 \%=22$

Our study has been extended to reactions of Y-substituted phenyl benzenesulfonates. 1a-g with $\mathrm{HOO}^{-}$ion (Scheme 1). The kinetic results were compared with those reported recently for the corresponding reactions with $\mathrm{HO}^{-}$ion $^{25}$ to investigate the origin of the $\alpha$-effect. We wish to report the

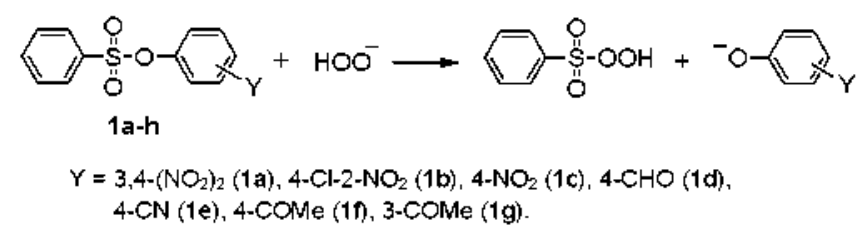

Scheme 1 
mechanism for the reactions of $1 \mathrm{a}-\mathrm{g}$ with $\mathrm{HOO}^{-}$ion and the origin of the $\alpha$-effect shown by $\mathrm{HOO}^{-}$ion.

\section{Results and Discussion}

All reactions in this study were performed under pseudofirst-order conditions with the concentration of $\mathrm{HOO}^{-}$in excess over the substrate concentration and obeyed first-order kinetics with quantitative liberation of Y-substituted pheno.ide. Pseudo-first-order rate constants ( $\left.k_{\text {obsd }}\right)$ were determined from the equation $\ln \left(A_{s}-A_{t}\right)=-k_{\text {obsil }} t+C$. The plots of $k_{\text {otsd }} v s$. $\left[\mathrm{HOO}^{-}\right]$were linear passing through the origin. indicating that contribution of $\mathrm{H}_{2} \mathrm{O}$ to $k_{0 \text { bsd }}$ is negligible in this study. Thus. the rate law is given by eq ( 1 ) and second-order rate constants ( $\left.k_{\mathrm{H}} \mathrm{n}_{-}\right)$were determined from the slope of linear plots of $k_{\mathrm{obsd}}$ vs. $\left[\mathrm{HOO}^{-}\right]$. It is estimated from replicate runs that the uncertainty in rate constants is less than $\pm 3 \%$. The $k_{\mathrm{H}}$ - values determined in this way are summarized in Table 1.

$$
\text { rate }=k_{\text {obsud }}[\text { substrate }] \text {. where } k_{\text {obsd }}=k_{\mathrm{H}_{1}-\mathrm{o}_{-}}\left[\mathrm{HOO}^{-}\right]
$$

Effect of Leaving-Group Basicity on Reactivity: Bonstedtype Comelation. As shown in Table 1, the second-order rate constants ( $\left.k_{\mathrm{H}}-\mathrm{I}^{-}\right)$decreases as the leaving group basicity increases. e.g. $k_{\mathrm{H}} i^{-}$decreases from $49.5 \mathrm{M}^{\cdot{ }^{-1}} \mathrm{~s}^{.1}$ to 2.53 and $0.1+9 \mathrm{M}^{-1} \mathrm{~s}^{-1}$ as the $\mathrm{p} K_{\mathrm{a}}$ of the conjugate acid of the leaving aryloxide increases from 5.42 to 7.14 and 9. 19. in thurn. A similar result is shown for the corresponding reactions with $\mathrm{OH}^{-}$ion. However. $\mathrm{HOO}^{-}$ion is more reactive than $\mathrm{OH}^{-}$ion toward all the substrates studied. although the former is less basic than the latter by $c a .4 \mathrm{p} K_{\mathrm{a}}$ units. ${ }^{\star \varsigma}$ The origin of the enhanced reactivity shown by $\mathrm{HOO}^{-}$ion (i.e., the $\alpha$-effect) will be discussed later.

The effect of leaving group basicity on reactivity for the reaction of $1 \mathrm{a}-\mathrm{g}$ with $\mathrm{HOO}^{-}$is illustrated in Figure 1. The Bronsted-type plot is linear with $\beta_{\mathrm{g}}=-0.73$. Interestingly, $\mathbf{1 b}$. which possess a $\mathrm{NO}_{2}$ group at the 2-position in the phenyl ring of the leaving ary loxide, does not exhibit negative deviation from the linearity. However. this is in contrast to the report that substrates possessing the substituent at the 2-position of the leaving aryloxide (e.g. 2- $\mathrm{Cl}$ or 2-NO2) exhibit large

Table 1. Sunnmary of Second-Order Rate Constants for Reactions of Y-Substituted Phenyl Benzenesulfonates (1arg) with $\mathrm{HOO}^{-}$and $\mathrm{OH}^{-}$in $\mathrm{H}_{2} \mathrm{O}$ at $25.0 \pm 0.1^{\circ} \mathrm{C}{ }^{\sigma}$

\begin{tabular}{|c|c|c|c|c|}
\hline \multirow[b]{2}{*}{ Y } & \multirow[b]{2}{*}{$p K_{\mathrm{a}}{ }^{\mathrm{Y} \cdot \mathrm{Ph} \mathrm{DH}}$} & \multicolumn{2}{|c|}{$k_{\mathrm{N}} / \mathrm{M}^{-1} \mathrm{~s}^{-1}$} & \multirow[b]{2}{*}{$\begin{array}{c}\alpha \text {-effect } \\
k_{\mathrm{Hoo}} / h_{\mathrm{OH}^{-}}\end{array}$} \\
\hline & & $\begin{array}{l}k_{\mathrm{HDOO}}-/ \\
\mathrm{M}^{-1} \mathrm{~s}^{-1}\end{array}$ & $\begin{array}{l}10^{2} \text { fiDH- } \\
\mathrm{M}^{-1} \mathrm{~s}^{-1}\end{array}$ & \\
\hline la $3,4-\left(\mathrm{NO}_{2}\right)=$ & 5.42 & 49.5 & 129 & 38.4 \\
\hline $1 \mathrm{~b}+-\mathrm{Cl}-2-\mathrm{NO}$ & 6.46 & 25.4 & 62.2 & 40.8 \\
\hline $1 c 4-\mathrm{NO}_{2}$ & 7.14 & 2.53 & 4.91 & 51.5 \\
\hline $1 \mathrm{~d} 4-\mathrm{CHO}$ & 7.66 & 1.18 & 1.73 & 68.2 \\
\hline 1e $4-C N$ & 7.95 & 0.617 & - & - \\
\hline If $4-\mathrm{COCH}_{3}$ & 8.05 & 0.596 & 1.94 & 30.7 \\
\hline $1 \mathrm{~g} 3-\mathrm{COCH}_{3}$ & 9.19 & 0.149 & 0.350 & 42.6 \\
\hline
\end{tabular}

${ }^{a}$ Data for the reactions of $1 \mathrm{a}-\mathrm{g}$ with $\mathrm{OH}^{-}$in $20 \mathrm{~mol}^{\circ}$. DMSO were taken from ref. 25.

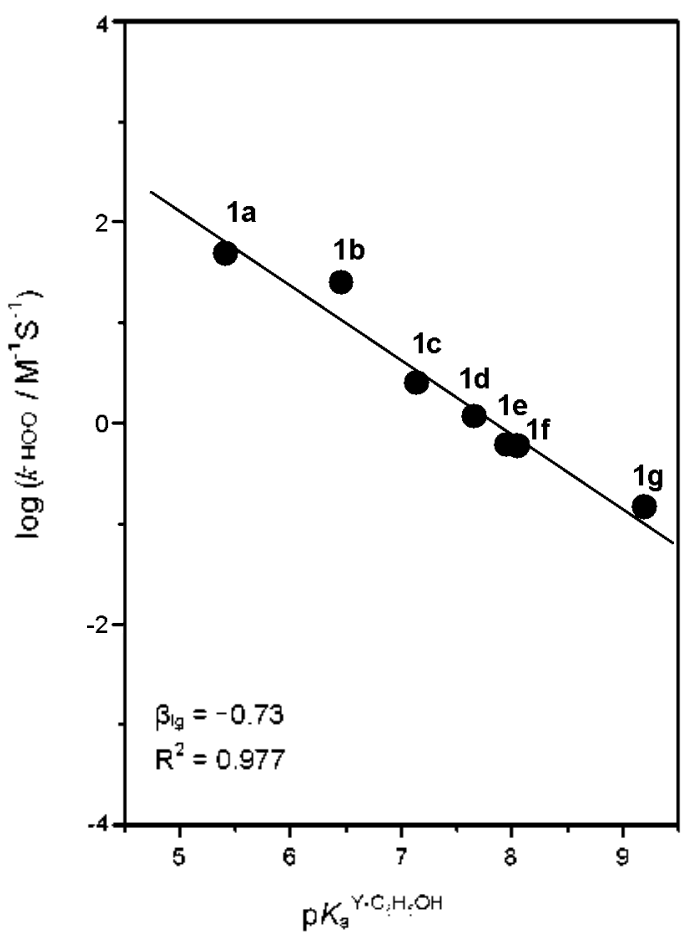

Figure 1. Bronsted-type plot for reactions of Y-substituted phenyl benzenesulfonates ( $1 \mathrm{a}-\mathrm{g}$ ) with $\mathrm{HOO}^{-}$and $\mathrm{OH}^{-}$in $\mathrm{H}_{2} \mathrm{O}$ at $25.0 \pm 0.1$ ${ }^{\circ} \mathrm{C}$. The identity of points is given in Table $\mathrm{l}$.

negative deviation from linear Bronsted-type plots (e.g. 2.4dinitrophenyl phenyl carbonate, ${ }^{27}$ 2.4-dinitrophenyl benzoate, ${ }^{x_{a}}$ 2-furoate ${ }^{280}$ and thiophene-2-carbosylate ${ }^{2-c}$ ). Thus, one can suggest that steric lindrance by the 2-nitro group in $1 \mathrm{~b}$ is absent. Absence of steric hindrance has also been reported for nucleophilic displacement reactions a $\mathrm{P}$ center. e.g., reactions of $\mathrm{Y}$-substituted phenyl diphenylphosphinates with anines. hydroxide and ethoxide ions.

Two factors can account for the absence of steric hindrance in the reaction of $\mathbf{1 b}$. i.e. the size and type of hybridization of the electrophilic center. The sulfonates 1a-g, like the phosphinate esters. have a much larger electrophilic center than carboxylates (i.e. $\mathrm{O}=\mathrm{S}=\mathrm{O}$ rs. $\mathrm{C}=\mathrm{O}$ ). Thus, the steric hindrance from the 2-NO2 group would not be significant during nucleophilic attack by $\mathrm{HOO}^{-}$at the large electrophilic center. One can suggest that the type of hybridization is also responsible for the absence of steric hindrance in the current reactions. The hybridization of the $\mathrm{C}=\mathrm{O}$ bond in carboxylate esters is $\mathrm{sp}^{2}$ in the ground state (GS) but it becomes $\mathrm{sp}^{3}$ in the transition state (TS). Consequently, the TS for the reactions of carboxylate esters becomes more crowded than the GS. In contrast. the hybridization of the sulfonate or phosphinate esters changes from tetrahedral in the GS to trigonal bipyramidal in the TS. Accordingly: the TS for the reactions of sulfonate 1a-g becomes less crowded than the respective GS. This idea is consistent with the fact that $\mathbf{1 b}$ does not exhibit negative deviation from the linearity in Figure 1.

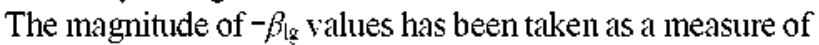
reaction mechanism. e.g. for reactions proceeding through a stepwise mechanism with an intermediate. $-\beta_{\text {lg }}$ has been reported to be ca. 0.8 or larger when breakdown of the inter- 
mediate is RDS, but $c a .0 .4$ or smaller when formation of the intermediate is $\operatorname{RDS}^{27,30 ;-32}$ On the other hand. for reactions proceeding through a concerted pathway $-\beta_{\text {lg }}$ has been reported to be $0.5 \pm 0.1$, e.g. reactions of Y-substituted phenyl dipheny lphosphinates and phosphinothioates with piperidine. lydroxide and ethoxide. ${ }^{29}$ The $-\beta_{\mathrm{g}}$ value of 0.73 found in the current reactions appears to be slightly larger than the $-\beta_{\text {lg }}$ value reported for a concerted mechanism. but is too large for reactions which proceed through a stepwise mechanism with formation of an intermediate being the RDS. Thus. the magnitude of the $-\beta_{\text {lg }}$ value alone cannot provide conclusive information on reaction mechanism.

Deduction of Reaction Mechanism from Hammett Conelation. To get more conclusive information on the mechanism for the current reactions. Hammett plots have been constnicted using $\sigma^{\circ}$ and $\sigma^{-}$constants. One might expect a better Hammett correlation with $\sigma^{-}$constants if expulsion of the leaving group occurs in the RDS whether the reaction proceeds in a concerted or a stepwise pathway. This is because a partial negative charge would develop on the oxygen atom of the leaving Y-substituted phenoxide, which can be delocalized on the substitnent $Y$ through resonance. when the leaving-group departure is advanced in the RDS. On the contrary. no negative charge would develop if expulsion of the leaving group occurs after the RDS. Then. $\sigma^{\circ}$ constants would result in better correlation than $\sigma^{-}$constants.

As shown in Figure 2. $\sigma^{-}$constants exhibits a better Hammett correlation than $\sigma^{\circ}$ constants. indicating that expulsion of the leaving group occurs at the RDS either in a concerted mechanism or in a stepwise pathway. However, one can exclude a stepwise mechanism in which departure of the leaving group

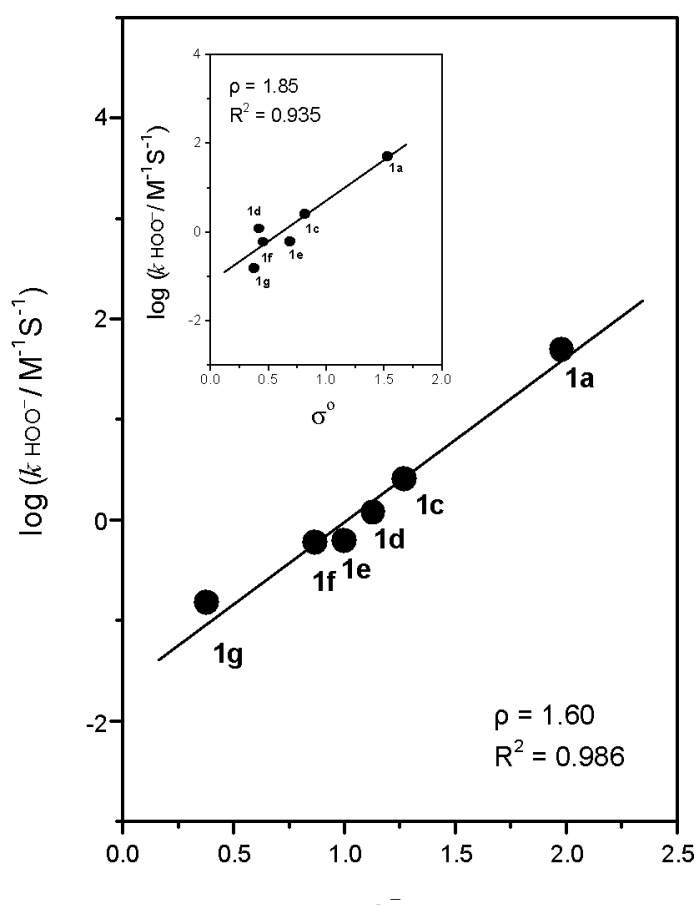

$\sigma^{-}$

Figure 2. Hanmett correlations with $\sigma^{-}$and $\sigma^{\circ}$ constants (inset) for reactions of Y-substituted phenyl benzenesulfonates (1a-g) with $\mathrm{HOO}^{-}$in $\mathrm{H}_{2} \mathrm{O}$ at $25.0 \pm 0.1^{\circ} \mathrm{C}$. occurs in the RDS. since $\mathrm{HOO}^{-}$ion is more basic and a poorer leaving group than all Y-substituted phenoxide ions studied. Thus. one can conclude the reaction of $1 \mathrm{a}-\mathrm{g}$ with $\mathrm{HOO}^{-}$ion proceeds through a concerted mechanism. The reactions of 1a-g with $\mathrm{OH}^{-}$ion in $20 \mathrm{~mol} \%$ DMSO has been reported to proceed also through a concerted mechanism on the basis of a linear Bronsted-type plot with $\beta_{\mathrm{g}}=-0.55$ and a linear YukawaTsuno plot with $\rho_{\mathrm{Y}}=1.83$ and $r=0.52 .{ }^{35}$

Origin of the $\alpha$-Effect. As discussed in the preceding section, $\mathrm{HOO}^{-}$is more reactive than $\mathrm{OH}^{-}$(i.e.. the $\alpha$-effect) although the former is $c a .+\mathrm{p} K_{\mathrm{i}} \mathrm{un}$ uts less basic than the latter. Since the reactions of $\mathbf{1 a - g}$ with $\mathrm{HOO}^{-}$and $\mathrm{OH}^{-}$proceed through a common mechanism, the $\alpha$-effect shown by $\mathrm{HOO}^{-}$is not due to a difference in reaction mechanism.

Stabilization of the TS through 5-membered intramolecular $\mathrm{H}$-bonding (e.g., 2) has been suggested to be more important than destabilization of the GS for reactions of Y-substituted phenyl benzoates with hydrazine and glycylglycine, as an $\alpha$ nucleophile and a reference nucleophile respectively $:^{-3}$ This is because such 5 -membered structure 2 is not possible for the corresponding reactions with the reference nucleophile, glycylglycine.

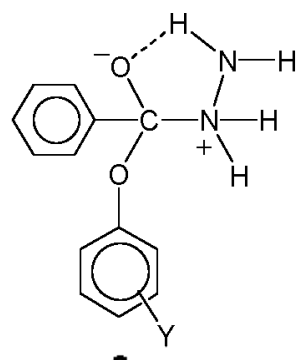

2

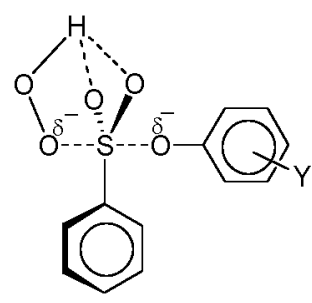

3
The TS for reactions with $\mathrm{HOO}^{-}$can be stabilized by forming intramolecular $\mathrm{H}$-bonding structure 3 . Since such $\mathrm{H}$-bonding structure is not possible for the corresponding reactions with $\mathrm{OH}^{-}$. one might suggest that TS stabilization through the $\mathrm{H}$-bonding interaction is responsible for the $\alpha$ effect found in the current reactions. However. if such TS stabilization is responsible for the $\alpha$-effect. one might expect that the $\alpha$-effect should be dependent on the electronic nature of the substituent $\mathrm{Y}$. This is because the $\mathrm{H}$-bonding interaction would be dependent on the electronic nature of the substituent Y. However, in fact. the magnitude of the $\alpha$-effect (i.e. $k_{\mathrm{H}: \mathrm{w}} /$ $\left.k_{\mathrm{CH}^{-}}\right)$ranges from 30 to 68 but is clearly independent of the electronic nature of the substituent $Y$. indicating that TS stabilization through the intramolecular $\mathrm{H}$-bonding interaction is not responsible for the $\alpha$-effect. Accordingly. one can suggest that GS destabilization is more important for the $\alpha$-effect found in the current study. This idea is consistent with the report that $\mathrm{HOO}^{-}$is $12 \mathrm{kcal} / \mathrm{mol}$ less strongly solvated than $\mathrm{OH}^{-}$in $\mathrm{H}_{2} \mathrm{O}^{3.3}$

\section{Conclusion}

The current study has allowed us to conclude the following: (1) Hammett plot correlated with $\sigma^{-}$constants results in much 
better linearity than $\sigma^{\circ}$ constants. indicating that expulsion of the leaving group occurs in the RDS. (2) A stepwise mechanism in which departure of the leaving group occurs in the RDS is excluded since $\mathrm{HOO}^{-}$ion is more basic and a poorer leaving group than the leaving Y-substituted phenoxide ions. (3) The reactions of $1 \mathrm{a}-\mathrm{g}$ with $\mathrm{HOO}^{-}$ion proceeds through a concerted mechanism. (4) The $\alpha$-effect shown by $\mathrm{HOO}^{-}$ion is not likely by TS stabilization through intramolecular $\mathrm{H}$-bonding interaction since the magnitude of the $\alpha$-effect is independent of the substituent Y. (5) GS destabilization through desolvation of $\mathrm{HOO}^{-}$ion in $\mathrm{H}_{2} \mathrm{O}$ is responsible for the current $\alpha$-effect.

\section{Experimental Section}

Materials. Compounds 1a-g were prepared readily from the reactions of benzenesulfonyl chloride with Y-substituted phenol in anhy'drous ether in the presence of triethy lamine as reported previously. Other chemicals including hydrogen peroxide used were of the highest quality available. Doubly glass distilled water was further boiled and cooled under nitrogen just before use.

Kinetics. The kinetic study was performed with a UV-Vis spectrophotometer equipped with a constant temperature circulating bath to maintain the temperature in the reaction cell at $25.0 \pm 0.1^{\circ} \mathrm{C}$. The reaction was followed by monitoring the appearance of the leaving Y-substituted phenoxide ion. All the reactions were carried out under pseudo-first-order conditions in which the $\mathrm{HOO}^{-}$concentration was at least 30 times greater than the substrate concentration. $\mathrm{The}_{2} \mathrm{H}_{2} \mathrm{O}_{2}$ stock solution of ca. $0.2 \mathrm{M}$ was prepared in a $25.0 \mathrm{~mL}$ vol. flask. Since $\mathrm{H}_{2} \mathrm{O}_{2}$ is not stable in a basic solution. $\mathrm{HOO}^{-}$was directly generated in the UV cell by adding 0.2 equiv: of $\mathrm{NaOH}$ solution to 1.2 equiv. of $\mathrm{H}_{2} \mathrm{O}_{2}$ solution to maintain a constant $\left[\mathrm{HOO}^{-}\right]$concentration by keeping the buffer ratio $\left[\mathrm{H}_{2} \mathrm{O}_{2}\right]$ $\left[\mathrm{HOO}^{-}\right]$at $5 / 1$ just before starting the reaction. All solutions were transferred by gas-tight syringes.

Product Analysis. Y-Substituted phenoxide was liberated quantitatively and identified as one of the products by comparison of the UV-Vis spectrum at the end of reaction with the authentic sample under the experimental condition.

Acknowledgments. This work was supported by a grant from Korea Research Foundation (KRF-2008-C00500). Li-Ra Im is also grateful for the BK 21 Scholarship.

\section{References}

1. Edwards, J O.; Pearson, R. G. J. Am (Them. Soc. 1962, 8f, 16-24.

2. Hoz, S.; Buncel, E. Ist. J. Chem. 1985, 26, 313-319.

3. Wiberg, K. B. J. Ant. Chent. Soc. 1955, 77, 2519-2522.

4. Mclssac, T. E., Jr.; Subbaraman, T.: Mulhausen, H. A.; Behrman, E. T. J. Org. Chem. 1972,37, 1037-1041.

5. Curci, R. Di Furia, F. Int. J. Chem. Kinet 1975, 7, 341-349.

6. (a) Um, I. H.; Han, I. Y : Buncel, E. Chent. Eur: J. 2009, I5, 1011-1017. (b) Buncel, E.: Um, I. H. Tetrahedron 2004, 60, 7801-7825. (c) Buncel, E.; Un, I. H.; Terrier, F. The Chemistry of Hydroxylamines, Oximes and Hydroxamic Acids: Wiley Press: West Sussex; 2009; Chapter 17

7. (a) Kirby, A. I: Tondo, D. W: Medeiros, M. Souza, B. S.; Priebe, J. P.; Lima, M. F.: Nome, F. J. Am. Chem. Soc. 2009 ,
131, 2023-2028. (b) Kirby, A. J.: Lima, M. F.: da Silva, D.; Rollssev, C. D.: Nome, F. J. Am. Chem. Soc. 2006, 128, 16944-16952. (c) Kirby, A. J.; Dutta-Rov, N.; da Silva, D.; Goodman, I. M.: Lima, M. F.: Rollssev, C. D.; Nome, F. J. Am. Chent. Soc. 2005, 127, 7033-7040.

8. (a) Terrier, F; Rodriguez-Dafonte, P; Le Guevel, E.; Moutiers, G. Oig. Biomol Chem 2006, 4,43524363 . (b) Terrier, F.: Le Guevel, E:- Chatrousse, A. P.; Moutiers, G.; Buncel, E. Chem. Commin. 2003, 600-601. (c) Buncel, E. Cannes, C.: Chatrollsse. A. P: Terrier, F. J. Am. Chem. Soc. 2002, 124, 8766-8767. (d) Moutiers, G.; Le Guevel, E.; Cannes, C.; Terrier, F. Buncel, E. Eur. J. Org. Chem. 2001, 17, 3279-3284

9. (a) Fountain, K. R. J. Phws. Org. Chem. 2005, 18, 481-485. (b) Fountain, K. R.; Felkerson, C. T.; Driskell, J. D.; Lamp, B. D. $J$. Org. Chem. 2003, 68, 1810-1814. (c) Fountain. K. R.: Tad-y, D. B.; Paul, T. W.; Golynskiy, M. V. J. Org. Chem. 1999, 64, $6547-6553$

10. Gregory, M. J.: Brulice, T. C. J. Am. Chem. Soc. 1967, 89, $4400-4405$

11. (a) Tencks, W. P. Catahsis in Chemistry and Enzmologv; McGraw-Hill: New York, 1969; pp 107-111. (b) Herschlag, D.; Jencks, W. P. J. Am. Chem. Soc. 1990, 112, 1951-1956. (c) Jencks. W. P. Chem Rev 1985, 85, 511-526. (d) Tencks. W. P.: Gilchrist, M. J. Ant. Chent. Soc. 1968, 90, 2622-2637.

12. (a) Bernasconi, C. F.: Leyes, A. E.; Eventova, I.; Rappoport, Z. J. Am. Chem. Soc. 1995, 117, 1703-1711. (b) Bernasconi, C. F. Adr. Phvs. Org. Chem. 1992, 27, 119-238. (c) Bemasconi, C. F.; Stronach, M. W. J. Org. Chem. 1991, 56, 1993-2001.

13. (a) Villano, S. M; Eyet, N.; Lineberger, W. C.; Bierbaum, V. M. J.Am. Chent Soc. 2009, 131, 8227-8233. (b) Depuy, C. H, Della, E. W.; Filley, I.: Grabowski, J. J.: Bierbaum, V. M. J. im Chem. Soc. 1983, 105, 2481-2482.

14. Patterson, E. V.: Fountain, K. R. J. Org. Chem. 2006, 71, $8121-8125$

15. McAnoy, A. M.; Paine, M. R; Blanksby, S. J. Org. Biomol. Chem 2008, 6, 2316-2326.

16. (a) Ren, Y.; Yamataka, H. J. Conput. Chem. 2009, 30, 358-365. (b) Ren, Y. Yamataka, H. J. Org. Chent. 2007, 72, 5660-5667. (c) Ren, Y, Yamataka, H. Chem. Em. J. 2007, 13,677-682. (d) Ren, Y, Yamataka, H. Org. Lent. 2006, 8, 119-121

17. (a) Buncel, E.; Um, I. H. Chem. Conmm. 1986, 595-596. (b) Um, I. H.: Buncel, E. J. Omg. Chem. 2000, 65, 577-582

18. Um, I. H.; Hwang, S. J.; Buncel, E. J. Org. Chent. 2006, 7l, $915-920$.

19. Un1, I. H.; Shin, Y. H; Han, J. Y; Buncel, E. Can. J. Chem. 2006, $84,1550-1556$

20. (a) Um, I. H.; Hong, I. Y; Buncel, E. Chem. Conmm. 2001, 27-28. (b) Tarkka, R. M. Buncel, E. J. Am. Chem. Soc. 1995, $117,1503-1507$

21. (a) Um, I. H.: Park, Y. M.; Buncel, E. Chem. Commm. 2000. 1917-1918. (b) Um, I. H.; Lee, E. T.; Buncel, E. J. Ong. Chem. $2001,66,4859-4864$.

22. Um, I. H.; Buncel, E. J. Am. Chem. Soc. 2001, 123, 11111-11112.

23. Um, I. H.; Chung, E. K.; Lee, S. M. Con. J. Chem. 1998, 76, $729-737$

24. Um, I. H: Han, J. Y: Shin, Y. H. J. Org. Chem. 2009, 74, $3073-3078$.

25. Un, I. H.: Im, L. R.: Park, Y. M. Bull. Korean Chem. Soc. 2008. $29,2477-2481$

26. Jenks, W. P.: Regenstein, I. In Handbook of Biochemistrv: Selected Data for Molectlar Biologv; Sober, H. A., Ed:; The Chemical Rubber Co.; Cleveland, OH, 1968.

27. (a) Gresser, M. I.; Tenks, W. P. J. Am. Chem. Soc. 1977, 99 , 6963-6970. (b) Gresser, M. J. Tenks, W. P. J. Ant. Chent Soc. $1977.99 .6970-6980$.

28. (a) Um, I. H.; Seo, J. A.; Lee, H. M. Bull. Korean Chem. Soc. 2008, 29, 1915-1919. (b) Um, I. H; Seo, J. A.; Chum, S. M. Bull. Kowean Chem. Soc 2008, 29, 1459-1463 (c) Um, I. H.: Akhtar, K. Bull. Korean Chem. Soc. 2008, 29, 772-776. 
29. (a) Unn, I. H.; Han, J. Y.: Hwang, S. I. Chem. Eur. J. 2008, 1H, 7324-7330), (b) Un, I. H.; Shin, Y. H.: Lee, S. E.: Yang, K.: Buncel, E. J. Org. (Them. 2008, 73, 923-930. (c) Um, I. H.: Akltar, K.; Shin, Y. H.; Han, I. Y. J. Org. Chem. 2007, 72, 3823-3829. (d) Um, I. H.; Park, J. E.; Shin, Y. H. Org. Biomol. Chem. 2007, 5, 3539-3543.

30. (a) Castro, E. A.: Campodonico, P. R.: Contreras, R.: Fuentealba, P.; Santos, T. G.; Leis, J. R.; Garcia-Rio, L.; Saez, J. A.; Domingo, L. R. Tetrahedron 2006, 62, 2555-2562. (b) Castro, E. A. Gazitua, M.: Santos, T. G. J. Org. Chem 2005, 70, 8088-8092

31. (a) Hoque, M. E. U.: Dey, S.; Guha, A. K.: Kim, C. K.: Lee, B. S.: Lee, H. W. J. Org Chem. 2007, 72, 5493-5499. (b) Oh, H. K.; Oh, J. Y.; Sung, D. D.: Lee, I. J. Org. Chent 2005, 70,5624-5629. (c) Lee, H. W: Guba, A. K, Kim, C. K.; Lee, I. J. Org. Chem. 2002, 67, 2215-2222. (d) Hoque, M. E. U.: Dey, N. K.: Guha, A K.; Kim, C. K.; Lee, B. S.; Lee, H. W. Bull. Konan Chem. Soc. 2007, 28, 1797-1802. (e) Hoque, M. E. U.; Lee, H. W. Bull. Kowem Chem. Soc. 2007, 28, 936-940.

32. (a) Um, I. H.; Park, Y. M.: Fuljo, M:; Mishima, M.; Tsuno, Y. J. Org. Chem. 2007, 72, 4816-1821. (b) Um, I. H.: Hwang. S. I.; Baek, M. H.; Park, E. J. J. Org. Chem 2006, 71,9191-9197. (c) Um. I. H.: Ko, S. H.: Bae, S. K. J. Oig. Chem. 2006, 71, 5800-5803. (d) Um, I. H.; Lee, H. W.; Nagano, Y.; Fujio, M: Tsuno, Y. J. Org. Chent. 2005, 70,4980-4987.

33. Ritchie, T. F. J. Am. Chem. Soc. 1983, 105, 7313-7318 